Original paper UDC 17.023.34:159.955(045)(083.77)

doi: $10.21464 / \mathrm{sp} 31207$

Received December $28^{\text {th }}, 2015$

\author{
Massimo Campanini \\ University of Trento, Department of Humanities, Via Gar 14, IT-38100 Trento \\ massimo.campanini@tiscali.it
}

\title{
Ontology of Intellect: The Happiness of Thinking in Averroës and Giordano Bruno ${ }^{1}$
}

\begin{abstract}
In this paper the author reflects comparatively on a specific issue dealt with by Giordano Bruno and Ibn Rushd: mental happiness. Mental happiness is intended here either as felicity through thinking or as felicity of thinking. The philosophical link between Averroës and Giordano Bruno is by now soundly established and the paper is rather a theoretical than an historical analysis regarding Bruno's "Averroism".
\end{abstract}

\section{Keywords}

Giordano Bruno, Ibn Rushd (Averroës), Bruno's Averroistic gnoseological framework, mental happiness

While I am not, strictly speaking, a scholar of Giordano Bruno, I have studied his theoretical works since my MA thesis $\mathrm{Il}$ concetto dell'infinito in Giordano Bruno (1977) at length. On the other hand, I am a scholar of Ibn Rushd (Averroës) and I have devoted many writings to his thought. ${ }^{2}$ In this article, I should like to reflect comparatively on a specific issue both philosophers dealt with: mental happiness. Mental happiness is intended here either as felicity through thinking, or as felicity of thinking. The philosophical link between Averroës and Giordano Bruno is by now soundly established. Bruno knew very well either Averroës' commentaries on Aristotle, or Averroës' Destructio destructionis (Tahäfut al-Tahäfut). This point is taken for granted here. Many previous works ${ }^{3}$ have already clarified what Giordano Bruno's "Averroism" is. In this paper, I will set out a theoretical more than historical analysis.

I warmly thank Professor Miguel Ángel Granada (University of Barcelona) for the useful remarks on the first draft of this article. 2

See at least the comprehensive monograph Massimo Campanini, Averroè, Il Mulino, Bologna 2007.

3

See, e.g., Rita Sturlese, “Averroes quantumque arabo et ignorante di lingua greca... Note sull'Averroismo di Giordano Bruno", Giornale critico della filosofia italiana 70 (1992), pp. 248-275; Eugenio Canone, "Giordano Bruno lettore di Averroè", in: Carmela Baffioni (ed.), Averroes and the Aristotelian Heritage, Guida, Napoli 2004, pp. 211-247; Gilberto Sacerdoti, Sacrificio e sovranità: Teologia politica nell'Europa di Shakespeare e Bruno, Einaudi, Torino 2002; Miguel Ángel Granada, Giordano Bruno, Herder, Barcelona 2002; and Miguel Ángel Granada, La rivendicacion de la filosofia in Giordano Bruno, Herder, Barcelona 2005. 


\section{Averroës: Gnoseology and politics}

The famous statement by Averroës in his commentary to Aristotle's $\mathrm{Ni}$ comachean Ethics is well-known: "ultima perfectio hominis est ut sit perfectus per scientias speculativas et hoc est sibi ultima felicitas et vita perfecta". Knowledge is the highest goal of human activity, and a knowing man/ woman acquires his/her highest perfection and felicity. It is an Aristotelian issue, deemed to be "averroistic", ${ }_{4}^{4}$ but in Averroës it has, at the same time, gnoseological, theological, and political implications. For, on the one hand, Averroës nurtured an elitist conception of philosophy. The philosopher is the one who uses the most refined and complex intellectual instruments and tools in order to formulate truth (haqq in Arabic) in the best, most compelling and convincing way. While religious truth responds to the gnoseological needs of the masses, philosophical truth responds to the gnoseological needs of the true learned people. Truth is one but is formulated in two - or even more - different languages ("truth does not oppose truth but is consistent with it and bears witness to it"; al-haqq là yudadd al-haqq bal yuwäfiquhu wa yashhadu lahu). ${ }^{5}$ Before the opposing languages of the people and of the philosophers, the dialectic and sophistic approach of the theologians is un-useful or rather pernicious. ${ }^{6}$ Moreover, only the philosopher has the possibility of approaching God through the perfection of intellect: his/her intellective faculties are divine and guarantee him/her to become similar to God and acquire happiness.

On the other hand, the philosopher's capacity to grasp the purest form of truth and to interpret more correctly and bindingly God's revelations implies that he/she has the right, or better the duty, to rule, as Plato and al-Fārābī contended before Averroës. At least, the philosopher has the right, indeed the duty, to counsel the ruler, so that he can govern in agreement with justice and the law. Philosophy becomes the strongest support of the normative provisions of religious Law.

The political commitment of Averroës runs throughout his work. ${ }^{7}$ However, in the Middle Commentary on Plato's Republic Averroës puts forward his philosophical advice to the Almohad caliph in order to rule the state in agreement with religious Law. ${ }^{8}$ The Middle Commentary on Plato's Republic, in other words, is a plaidoyer for an Islamic government inspired by philosophy. ${ }^{9}$ Averroës urged the Almohad caliphs (he served them as a physician and a judge) to reform the politeia through philosophy, supporting shari 'a by the sophisticated and sound instruments of theoretical speculation.

On the other hand, in his commentaries on Aristotle's De anima and in his Epistle on Conjunction, Averroës throws human intellect towards the empyrean of celestial beauty and luminosity. I cannot deal with this doctrine in detail; I will simply try to sum it up briefly.

The universe is a hierarchy of motors (the separate Intellects) that move the moved through intellectual passion and Love.

"This first mover imparts motion, without being moved, to the first object moved by it, just as the beloved moves his lover without being moved itself, and it imparts motion to what is below its first moved by means of the first moved. By its first moved, he [Aristotle] means the celestial body, and by all the other moved, that which is below the first body, namely, all the other spheres and that is subject to generation and corruption. The first heaven is moved by this mover by means of its desire for it, I mean, because it imitates it according to its ability, as the lover is moved to [imitate] the beloved. All the other celestial bodies are moved by their desire for the motion of the first body." 10 
God, the First Unmoved Mover, is the beloved who moves the lover, which is the celestial body, the First Heaven. The First Heaven is the first moved and is moved by the loving desire that it feels for God. God is the First Mover that moves all the other spheres, but not directly as the First Heaven, but indirectly through the mediation of the First Heaven itself. Thus, the First Heaven moves the other spheres and the spheres are moved by the loving desire they feel for the first moved.

Averroës points out that this order of movers and movements is put in action by the intellectual representation:

4

Keenly, as usual, Alain De Libera summed up: "Né dans la faculté des arts, le courant qui a nourri l'exaltation de la vie philosophique come telle peut être appelé 'l'aristotélisme radical', mais on pourrait l'appeler aussi 'aristotélisme éthique'. Il se définit par la rencontre d'une psychologie philosophique particulière - la théorie de l'intellect du péripatétisme gréco-arabe - mise au service de l'interprétation de la signification éthique et métaphysique de la contemplation philosophique - la 'sagesse théorétique' d'Aristote. [...] Comme le soulignera Dante, la vie selon l'intellect est 'la fin de toute la société humaine' (Monarchia, I, 3, 1)." Alain De Libera, La philosophie médiévale, PUF, Paris 1989, pp. 122-123. Later, De Libera partially changed his mind arguing that it is improper to call "averroisme éthique" a doctrine almost entirely derived by Albertus Magnus (see Alain De Libera, Raison et foi. Archèologie d'une crise d'Albert le Grand à Jean Paul II, Seuil, Paris 2003). Luca Bianchi remembers, in a very recent article, that Carlos Steel and Gianfranco Fioravanti also neatly divided the ideal of philosophical life from the copulatio with the separated Intellects, framing that ideal rather in the institutional context of the medieval faculties of arts (Luca Bianchi "L'Averroismo di Dante", Le Tre Corone 1 (2015), pp. 96-97). The iconoclasm of all the old interpretative paradigms, however, risks to prevent giving any name to whichever phenomenon.

Averroè, Il Trattato Decisivo sulla connessione della religione con la filosofia, ed. by Massimo Campanini, BUR Rizzoli, Milano ${ }^{3} 2015$, p. 69. The Fasl al-maqāl has been translated many times. Here, I remember Alain De Libera and Marc Geoffroy's Discours Décisif, Flammarion, Paris 1996 (the quoted sentence on p. 119), and Charles Butterworth, Decisive Treatise and Epistle Dedicatory, Brigham Young University Press, Provo, UT 2001.

It is necessary to briefly stress this point. How coordinating and connecting (not harmonizing) are the multifarious expressive moods through which the unique Truth shows itself? How does one make two odd propositions like "the world is created" and "the world is eternal" consistent? Through language, Averroës answers. Through the language of the masses we approach truth; through the philosophers' language we grasp it. Through language we acknowledge that "the world is created" and "the world is eternal" express the same truth in two different linguistic shapes. This very problematic solution, however, makes theologians marginal because theology's language deceives the simple people, on the one hand, while it does not convince the true learned, on the other. See also Oliver Leaman, Averroes and his Philosophy, Clarendon Press, Oxford 1988.

See Charles Butterworth, Philosophy, Ethics and Virtuous Rule: A Study of Averroes' Commentary on Plato's Republic, Cairo Papers in Social Sciences, Cairo 1985. More recent is Rosalie De Souza Pereira, Averróis: $A$ arte de governar, Perspectiva, São Paulo 2012. See also Massimo Campanini, "Averroè lettore di Aristotele: un problema politico?", in C. Baffioni (ed.), Averroes and the Aristotelian Heritage, pp. 35-47, where I argue that even Averroës' Aristotelian commentaries are understandable in the perspective of the theological-political connection between philosophy and religion.

See Ralph Lerner (ed.), Averroes on Plato's Republic, Cornell University Press, Ithaca, NY 1973

See Massimo Campanini, Islam e politica, Il Mulino, Bologna ${ }^{3} 2015$, pp. 151-156.

10

Ibn Rushd's Metaphysics: A Translation with Introduction of Ibn Rushd's Commentary on Aristotle's Metaphysics Book Lam, ed. by Charles Genequand, Brill, Leiden 1986, textus 37, p. 154 (cf. Long Commentary on De Anima of Aristotle, ed. by Richard Taylor, Yale University Press, New Haven - London 2009). 
"Having explained that the first mover is eternal, substance, pure actuality and free from matter, that it imparts motion without being moved but as object of desire and pleasure and that the principle of all motion is from something and towards something, he [Aristotle] wants to tell us what the principle of this motion in the object moved is and what the object towards which there is motion is, and says: 'the principle is intellectual representation', meaning the principle of this motion in the celestial body is intellectual representation." 11

In this cosmic structure, the Active Intellect carries out - in relation to the human intellect - the same function the First Immobile Mover carries out in relation to the celestial Intellects: it moves insofar as it is loved, insofar as it is an object of love and final cause. Through conjunction, copulatio, humans, or better said philosophers, conquer and acquire supreme happiness, mental or intellectual happiness:

"It clearly appears from that which Aristotle thinks that happiness for men qua men consists in this contact with the intellect which has been shown in De Anima to be the principle, the mover and agent for us. The separate intellects qua separate must be the principle of that of which they are principles in both senses, I mean as movers and as ends. The active intellect, insofar as it is separate and principle for us, must move us in the same way as the beloved moves the lover and if every motion must be in contact with the thing which produces it as an end, we must ultimately be in contact with this separate intellect." 12

Possibly, this is the unique way through which the human being, or better the philosopher, can acquire personal immortality which, as in al-Fārābī, is selective and proper not of the individual but of the species. The human being, or better the philosopher, fully realizes himself/herself in the conjunction or copulatio and leads the cosmic fabric to its factual perfection.

In conjunction, the human material or possible intellect vanquishes. Having achieved its supreme perfection, its entelechia, the material or possible intellect loses all potentiality and, joining the ontologically higher Active Intellect, it dissolves itself within the Active Intellect. As the fire burns a combustible body and transforms it in its own nature, ${ }^{13}$ thus the Active Intellect (the fire), in contact with the material intellect (the combustible body), burns it and transforms it into its own nature. Only the unique, immortal and separate Intellect remains in existence. It becomes more than the factual content of the human mind when it thinks of God and is imbued of God; it becomes the human mind itself. When a human being achieves conjunction, he/she cannot but become immortal as God is immortal. However, this immortality is not individual, but impersonal plunged into the eternal permanence of the supreme Intellect itself.

The uniqueness and separateness of the Active Intellect coupled with the conviction that the material or possible intellect vanquishes within the Active Intellect in conjunction, leads us to believe that, in Averroës' view, the Intellect goes on to think also without humans. Ontology of intellect means that, uniting itself to God in conjunction, the intellect becomes a hypostasis which governs human individual intellects making them thinking.

As Alain De Libera summed up the issue:

"On sait que, par une sorte d'intériorisation de la critique thomiste, certains maitres du XIII siècle, tel l'Anonyme d'Oxford édité par M. Giele, on été jusqu'à refuser la pertinence de la proposition 'Homo intelligit' (c'est l'homme qui pense), et que, réfutant par avance toute psychologie du cogito ils se sont livrés à l'apologie la plus radicale de ce que J. Jolivet a appelé le 'décentrement' averroïste 'du sujet': l'homme ne pense pas, quelque chose - l'intellect - se sert de lui pour penser."14

Humans do not think by themselves: it is the supreme Intellect (God, far above the Active Intellect) which thinks through humans and, consequently, makes them immortal. ${ }^{15}$ 
The subject's dissolution - potentially implicit in this stance of Averroës'was firmly condemned by Thomas Aquinas who feared for the dissolution of morality and society:

"Manifestum est quod intellectus est id quod est principale in homine, et quod utitur omnibus potentiis animae et membris corporis tamquam organis; et propter hoc Aristotiles subtiliter dixit quod homo est intellectus 'uel maxime'. Si igitur sit unus intellectus omnium, ex necessitate sequitur quod sit unus intelligens, et per consequens unus uolens et unus utens pro suae uoluntatis arbitrio omnibus illis secundum quae homines diuersificantur ad inuicem. Et ex hoc ulterius sequitur quod nulla differentia sit inter homines quantum ad liberam uoluntatis electionem, sed eadem sit omnium, si intellectus apud quem solum residet principalitas et dominium utendi omnibus aliis, est unus et indiuisus in omnibus. Quod est manifeste falsum et impossibile: repugnat enim hiis quae apparent, et destruit totam scientiam moralem et omnia quae pertinent ad conuersationem ciuilem, quae est hominibus naturalis, ut Aristotiles dicit."16

This is but one of the many suspect achievements of Averroës' philosophy that fed his atheistic fame. Nevertheless, Augusto Illuminati put forward a positive evaluation of Averroës' unity of intellect. For, in Illuminati's view, the unity of intellect foresees the contemporary constitution of a general intellect using a shared and common language and a shared and common communicative competence (like the web nowadays, for example). The subject's dissolution is overcome in the common intellect:

"[...] my opinion is that the possible intellect's unity for all humans is a metaphor of the linguistic competence and foresees a dominant theme of contemporary culture: the dissolution of the subject's unity and the laying of stress on the objective structures of communication and meaning-construction. While in the Middle Ages this led to the impossibility of believing in an individual immortal soul subjected to eternal punishment or rewards, today, it leads to the impossibility of private solipsistic languages, rather enhancing the existence of a public intellect (the Marxian general intellect) within which the common human linguistic and communicative competence works." 17

Happiness of thinking has a political outcome. In Averroës it implies the philosopher's right and duty to rule. How wonderful would it have been if the Almohad caliphs were philosophers! Unfortunately, they were not; so the philosopher (Averroës in point) must counsel and support them in the difficult art of government.

11

Ibid., textus 37, p. 151.

12

Ibid., textus 38, p. 157.

13

See The Epistle on the Possibility of Conjunction with the Active Intellect by Ibn Rushd with the Commentary of Moses Narboni, ed. by Kalman P. Bland, The Jewish Theological Seminary of America, New York 1982; Augusto Illuminati, Averroè e l'intelletto pubblico, Manifestolibri, Rome 1996, p. 187.

14

Alain De Libera, "Introduction", in: Averroès, L'Intelligence et la pensée: Grand commentaire du "De Anima" Livre III (429 a 10 - 435 b 25), Flammarion, Paris 1998, p. 21.

15

The Qur'ān gives the picture of the human being both as a Prometheus and a sinner:
"We [God speaking] offered the Trust to the heavens, the earth and the mountains, yet they refused to undertake it and were afraid of it; mankind undertook it - they have always been inept and foolish" (Q. 33:72, translation Abdel Haleem). Take, for example, two geniuses like Dante Alighieri and Galileo Galilei: both were highly egotistic and egocentric men, but they wrote the Divina Commedia and the Dialogo sui massimi sistemi. The Divine Intellect thought through them and made them immortal.

16

Divi Thomae Aquinatis, "De Unitate intellectus contra Averroistas", IV, 87, in: Thomas d'Aquin, Contre Averroès, ed. by Alain De Libera, Flammarion, Paris 1994, p. 162.

17

A. Illuminati, Averroè e l'intelletto pubblico, p. 10 . 


\section{Giordano Bruno and the intellectual magnificence of the "furioso"}

It is interesting to see how Giordano Bruno lived and interpreted the philosophical mission in his life even before his doctrine and theory. For Bruno said that the philosopher is not only the one who is moved by the "eroico furore". The philosopher is the one who is able to offer his/her life in order to defend and make triumphant the "Truth" even in a holocaust.

Bruno started from Averroës' thought and can be defined as an "Averroist", first of all in the elitism of philosophy. The philosopher is the one who "allarg[a] i [...] pensieri ad alta preda", like Atteone who "significa l'intelletto intento alla caccia della divina sapienza, all'apprension della beltà divina". ${ }^{18}$

As such, and according to Averroës, this task and goal cannot be pursued by any person:

"Rarissimi, dico, son gli Atteoni alli quali sia dato dal destino di posser contemplare la Diana ignuda, e dovenir a tale che dalla bella disposizione del corpo della natura invaghiti in tanto, e scorti da que' doi lumi del gemino splendor de divina bontà e bellezza, vegnano traformati in cervio, per quanto non siano più cacciatori ma caccia."19

There are very few philosophers who are able to fathom nature's secrets and thus grasp the factual essence of divinity. Therefore, their mission is elitist; it is a mission of knowledge and intellectual perfection and it can provoke their martyrdom and sacrifice against the masses' ignorance and the authorities' tyranny. ${ }^{20}$

The perspective of intellectual perfection through knowledge and conjunction runs throughout Giordano Bruno's works, as in Averroës. For example, in the Proemiale epistola of the Italian dialogue De l'infinito, universo e mondi we read that "[la] Filosofia che apre gli sensi, contenta il spirto, magnifica l'intelletto e riduce l'uomo alla vera beatitudine che può aver come uomo" is the philosophy that is put in motion by the intellectual power, "vuole e puote aggiungere spacio a spacio, mole a mole, unitade ad unitade, numero a numero".

Intellectual perfection leads to a transformation of morality and to the conquest of the new image of infinite nature - infinite in space and time:

"Non sono fini, termini, margini, muraglia che ne defrodino e suttragano la infinita copia de le cose. Indi feconda è la terra et il suo mare; indi perpetuo è il vampo del sole: sumministrandosi eternamente esca a gli voraci fuochi, et umori a gli attenuati mari; perché dall'infinito sempre nova copia di materia sottonasce. Ecco qua la raggione per cui non doviam temere che cosa alcuna diffluisca, che particolar veruno o si disperda, o veramente inanisca o si diffonda in vacuo che lo dismembre in adnihilazione. Ecco la raggion della mutazion vicissitudinale del tutto; per cui cosa non è di male da cui non s'esca, cosa non è di buono a cui non s'incorra: mentre per l'infinito campo, per la perpetua mutazione, tutta la sustanza persevera medesima et una. Dalla qual contemplazione $[. .$.$] aremo la via vera alla vera moralità, saremo magnanimi, spreggiatori$ di quel che fanciulleschi pensieri stimano, e verremo certamente più grandi che que' dei che il cieco volgo adora, perché dovenerremo veri contemplatori dell'istoria della natura, la quale è scritta in noi medesimi, e regolati executori delle divine leggi che nel centro del nostro core sono inscolpite." 21

This noble man, the philosopher, is the "furioso" who feels the heroic passion of connecting himself, of uniting himself with divinity. The philosopher's ("furioso"'s) intellect yearns for the union with the supreme divine Intellect. Commenting on his own sonnet Benché a tanti martir mi fai suggetto, in the Eroici furori Bruno argues that the intellectual power ("virtù dell'intelletto") realizes conjunction with God in such a way that intellect becomes God and God becomes intellect: 
"Cicada. Il divo dumque e vivo oggetto ch'ei dice, è la specie intelligibile più alta che egli s'abbia possuto formar della divinità; e non è qualche corporal bellezza che gli adombrasse il pensiero come appare in superficie del senso?

Tansillo. Vero: perché nessuna cosa sensibile, né specie di quella, può inalzarsi a tanta dignitade.

Cicada. Come dumque fa menzione di quella specie per oggetto, se (come mi pare) il vero oggetto è la divinità istessa?

Tansillo. La è oggetto finale, ultimo e perfettissimo; non già in questo stato dove non possemo veder Dio se non come in ombra e specchio, e però non ne può esser oggetto se non in qualche similitudine; non tale qual possa esser abstracta et acquistata da bellezza et eccellenza corporea per virtù del senso: ma qual può esser formata nella mente per virtù de l'intelletto. Nel qual stato ritrovandosi, viene a perder l'amore et affezzion d'ogni altra cosa tanto sensibile quanto intelligibile; perché questa congionta a quel lume dovien lume essa ancora, e per consequenza si fa un Dio: perché contrae la divinità in sé essendo ella in Dio per la intenzione con cui penetra nella divinità (per quanto si può), et essendo Dio in ella, per quanto dopo aver penetrato viene a conciperla e (per quanto si può) a ricettarla e comprenderla nel suo concetto."22

\section{Bruno explicitly acknowledges his indebtedness to Averroës:}

"Cicada. Mi par che gli peripatetici (come esplicò Averroe) vogliano intender questo quando dicono la somma felicità de l'uomo consistere nella perfezione per le scienze speculative.

Tansillo. È vero, e dicono molto bene; perché noi in questo stato nel qual ne ritroviamo, non possiamo desiderar né ottener maggior perfezione che quella in cui siamo quando il nostro intelletto mediante qualche nobil specie intelligibile s'unisce o alle sustanze separate, come dicono costoro, o alla divina mente, come è modo de dir de platonici." 23

In this Averroistic gnoseological framework, Bruno takes a heroic stance: the philosopher does not renounce the pursuing of his/her philosophical mission, defending his/her ideas and visions to the extent of martyrdom.

It does not matter here why Giordano Bruno returned to Italy, to Venice, in 1591 after many years spent, especially, in reformed countries. Rather, it is important to understand his behaviour during the trial. During the trial, Bruno enforced with constancy a defence plan grounded upon a dissimulation strategy. It was a complex plan: admitting what could not be concealed or what was, apparently, consistent with Catholic orthodoxy; denying energetically what appeared ambiguous or plainly anti-Catholic, if not antiChristian. ${ }^{24}$ This behaviour was a repeat of a strategy Bruno had already

18

Giordano Bruno, "Degli Eroici Furori”, in: Giordano Bruno, Dialoghi italiani, ed. by Giovanni Aquilecchia, Sansoni, Firenze 1958, p. 1006.

19

Ibid., p. 1124.

20

The myth of Atteone is thoroughly studied by Salvatore Carannante in Giordano Bruno e la caccia divina, Edizioni della Normale, Pisa 2013. Carannante demonstrates that the myth involves a harsh condemnation of Christianity as the enemy of nature and of a "true" conception of divinity. Catholic religious authorities cannot but read "heresy" and lack of belief in it.

21

Giordano Bruno, "De l'infinito, universo e mondi", in: G. Bruno, Dialoghi italiani, pp. 359-361 passim.
22

G. Bruno, “Degli Eroici Furori”, pp. 995-996. Admittedly, in other parts of the same dialogue Bruno says that the philosopher (Atteone) "se non la [Anfitrite] vede in sua essenza, in assoluta luce, la vede nella sua genitura che gli è simile, che è la sua imagine: perché dalla monade che è la divinitade, procede questa monade che è la natura, l'universo, il mondo" (ibid., p. 1125). Perhaps human intellect cannot attain divine reality and truth directly, but it has at its disposal the image of the "divina monade", which is nature.

23

Ibid., p. 998.

24

Luigi Firpo argued clearly that Bruno's defensive strategy "[consisteva] nel negare il negabile, nel giustificare - mediante opportune attenuazioni - quanto si poteva destramente conciliare col dogma cattolico, 
applied whilst writing his "moral" Italian dialogues, like the Spaccio della bestia trionfante - those more dangerous from a religious point of view. In the "moral" Italian dialogues, the Nolano covered with mythological dresses real characters and figures of the holy Bible, especially Christ. He dissimulated a Catholic honesty in order to conceal his fierce critique of all historical religions. It is undoubtedly an "Averroistic" stance, insofar as it seems to involve a double standard of truth. ${ }^{25}$ "Averroistic" dissimulation is the defensive weapon Bruno used during the trial, in order either to conceal the more heterodox implications of his teaching and the more compromising episodes of his wandering life in reformed countries, or, on the other hand, to keep himself faithful to his philosophical and intellectual conquests. ${ }^{26}$

Speaking of his works to the judges of the Venetian Inquisition tribunal, Bruno said that

"La materia di tutti questi libri, parlando in generale, è materia filosofica [...] nelli quali tutti io sempre ho diffinito filosoficamente e secondo li principii e lume naturale, non avendo riguardo principal a quel che secondo la fede deve essere tenuto."27

Thus, dissimulation acquires a strong gnoseological and even theoretical value and, in the literary and humanistic tradition, could be connected to Erasmus from Rotterdam's (an author Bruno knew very well) Sileni, which seem outwardly deformed, but are, inwardly, pure and noble. In other words, Bruno's ideas are outwardly dangerous for traditional religious faith, but are, inwardly, philosophically sublime.

Dissimulation was not enough to save Bruno's life however. The philosopher was asked to choose between renouncing his ideas and deepest convictions, or dying. He chose death in the name of the truth he believed to have conquered. To be sure, the choice was not easy, but, once taken, it could not be renounced. When Bruno was summoned by the Roman Inquisition tribunal to listen to the death sentence, his behaviour was full of dignity and indeed of pride and rebellion:

"Fere biennio post, quam hic in Inquisitionem devenit, nupera die nona februarii in supreme Inquisitoris palatio, praesentibus illustrissimis cardinalibus Sancti Officii Inquisitionis [...], et consultoribus theologis, et saeculari magistratu Urbis gubernatore, fuit Brunus ille in locum Inquisitionis introductus; ibique genibus flexis sententiam contra se pronunciari audiit. Ea autem fuit huiusmodi: narrata fuit eius vita, studia et dogmata, et qualem Inquisitio diligentiam in convertendo illo et fraterne monendo adhibuerit, qualemque ille pertinaciam et impietatem ostenderit; inde eum degradarunt, ut dicimus prorsusque excommunicarunt et saeculari magistratui eum tradiderunt puniendum, rogantes ut quam claementissime et sine sanguinis profusione puniretur. Haec cum ita essent peracta, nihil ille respondit aliud, nisi minabundus: 'Maiori forsan cum timore sententiam in me fertis quam ego accipiam'. Sic a lictoribus gubernatoris in carcerem deductus, ibique octiduo asservatus fuit, si vel nunc errores suos revocare vellet; sed frustra. Hodie igitur ad rogum sive piram deductus, cum Salvatoris crucifixi imago ei iam morituro ostenderetur, torvo eam vultu aspernatus reiecit; sicque ustulatus misere periit, renunciaturus, credo, in reliquis illis, quos finxit, mundis, quonam pacto homines blasphemi et impii a Romanis tractari soleant." 28

Bruno paid for the turmoils and excesses of the late European Cinquecento, stained with the blood of the inter-Christian religious wars, with his life. Catholicism and Protestantism fought a mortal battle without a clear winner and a clear loser. Christianity was strengthened by the religious wars on the whole. Bruno's legacy fed the heterodox trends of European thought in the 17 th century from Baruch de Spinoza to John Toland, and his cry of freedom was not forgotten. 


\section{Conclusion}

The possibility of achieving happiness through thinking gives concreteness and, I dare to believe, nobility to philosophy. In different epochs and within different social and intellectual frameworks, Averroës and Bruno witnessed the value of that peculiar profession that is the profession of thinking. Both testified that philosophy must avoid self-complacency and rather comply with the needs and the problems of the epoch wherein it is practiced. In a sense, mental happiness is the outcome of a "secular" knowledge: religion (Islam in Averroës and pantheism - provided that pantheism is a religion - in Bruno ${ }^{29}$ ) is not the presupposition of mental happiness. The achievement of mental happiness is the outcome of pure human perfection, although it allows us to grasp God tentatively. Averroës and Bruno shared the political commitment of intellectual work: both thinkers deeply participated in their social and historical context. Therefore, politics represented the juncture between religion and knowledge and the supreme level of philosophizing.

nell'ammettere infine taluni non altrimenti riducibili errori, ripudiandoli e invocando per essi clemenza" (Luigi Firpo, Il processo di Giordano Bruno, ed. by Diego Quaglioni, Salerno Editrice, Rome 1993, p. 19). Bruno followed this strategy throughout the process. When in Venice, it was viable because the judges did not know his printed work; but later, in Santo Uffizio's prison in Rome, it was very dangerous, because the judges had then read a substantial part of his audacious and provocative books.

\section{5}

Obviously, it is an "Averroistic" stance, not a stance of Averroës! As I argued earlier, Averroës never said that there are two (or more) different truths. The Averroists did - not expressis verbis obviously, but by applying the paradigm in their works in practice. See Massimo Campanini, L'intelligenza della fede: Filosofia e religione in Averroè e nell'Averroismo, Lubrina, Bergamo 1989. The debate on the "double truth" is one of the richest in historiography and cannot be simplified and exhausted here. I shall resume this discussion in a forthcoming article on Aver- roës' and Bruno's religious ideas - in sha' allah.

26

The strict bond between the life and the thought of Bruno has been duly emphasized by Michele Ciliberto, Introduzione a Bruno, Laterza, Roma - Bari 2003.

27

Third questioning, 2 June 1592, in: L. Firpo, Il processo di Giordano Bruno, p. 166.

28

Kaspar Schoppius' letter on 17 February 1600, in: L. Firpo, Il processo di Giordano Bruno, pp. 351-352. My emphasis.

29

Bruno was plainly atheist, in my view, in the sense that he did not believe in the revealed God, but pantheism was for him the very basis of a new religious reformation. His God is not personal, it is the "divine" order of nature, dominated by rationality - almost a deist perspective. As I stated earlier, I hope to come back to this issue in a forthcoming article. 


\title{
Massimo Campanini \\ Ontologija intelekta: sreća mišljenja u Averroësa i Giordana Bruna
}

\begin{abstract}
Sažetak
U ovome radu autor komparativno promišlja o pitanju kojim su se bavili Giordano Bruno i Ibn Rušd (Averroës), a to je - intelektualna sreća. Pod intelektualnom srećom ovdje se misli ili na sreću kroz mišljenje ili na sreću mišljenja. Filozofska veza između Averroësa i Giordana Bruna već je čvrsto utemeljena, a rad je više teorijska nego historijska analiza u pogledu Brunova "averroizma».
\end{abstract}

Ključne riječi

Giordano Bruno, Ibn Rušd (Averroës), Brunov averroistički gnoseološki okvir, intelektualna sreća

\section{Massimo Campanini \\ Ontologie des Intellekts: das Glück des Denkens bei Averroës und Giordano Bruno}

\begin{abstract}
Zusammenfassung
In dieser Arbeit reflektiert der Autor komparativ über ein spezifisches Thema, das von Giordano Bruno und Ibn Ruschd behandelt wurde: geistiges Glück. Das geistige Glück ist hier entweder als Glück durch Denken oder als Glück des Denkens gedacht. Die philosophische Verbindung zwischen Averroës und Giordano Bruno ist mittlerweile fest etabliert und das Paper ist eher eine theoriebezogene als historische Analyse im Hinblick auf den „, Averroismus “ Brunos.
\end{abstract}

\section{Schlüsselwörter}

Giordano Bruno, Ibn Ruschd (Averroës), Brunos averroistischer gnoseologischer Rahmen, geistiges Glück

\section{Massimo Campanini \\ Ontologie de l'intellect : le bonheur de la pensée chez Averroès et Giordano Bruno}

\section{Résumé}

Dans cet article, l'auteur adopte une approche comparative pour aborder la question déjà traitée par Giordano Bruno et Ibn Rochd (Averroès) - question se rapportant à la chance intellectuelle. Le bonheur intellectuel est ici conçu, soit comme bonheur par la pensée, soit comme bonheur de la pensée. Le lien philosophique entre Averroès et Giordano Bruno a préalablement déjà été établi, et il sera davantage question dans cet article d'une analyse théorique qu'historique quant à l'" averroïsme » de Bruno.

\section{Mots-clés}

Giordano Bruno, Ibn Rochd (Averroès), cadre gnoséologique averroïque de Bruno, bonheur intellectuel 